\title{
OPTIMIZATION OF MUNICIPAL ENERGY SYSTEMS WITH THE USE OF AN INTELLIGENT ANALYTICAL SYSTEM
}

\author{
Piotr ZIEMBICKI ${ }^{1}$, Marcin KLIMCZAK ${ }^{2}$, Jan BERNASIŃSKI ${ }^{3}$ \\ ${ }^{1,3}$ University of Zielona Góra, Faculty of Civil Engineering, \\ Architecture and Environmental Engineering \\ ${ }^{2}$ Wrocław University of Science and Technology, Faculty of Environmental Engineering
}

\begin{abstract}
The paper presents the analytical and consultancy system which aims at a complex, comprehensive, multi-criteria energy performance analysis of a given building or a group of buildings and at making a recommendation for an energy source with regard to $\mathrm{CO}_{2}$ emission and investment costs determined on the basis of indicators included in the knowledge databases. The analytical and consultancy system employs advanced energy performance computer simulations of buildings as well as innovative analytical algorithms worked out and contributed by the authors, including those based on the knowledge base developed on the grounds of performance data from selected buildings of various types situated in a dozen or so cities of different population in Poland.
\end{abstract}

Keywords: energy systems, simulation, optimization, analytical systems, Smart City

\footnotetext{
${ }^{1}$ Corresponding author: University of Zielona Góra, Faculty of Civil Engineering, Architecture and Environmental Engineering, Prof. Z. Szafrana 15 St., 65-516 Zielona Góra, Poland, e-mail: P.Ziembicki@iis.uz.zgora.pl, phone +48 601942964
} 


\section{INTRODUCTION}

Both in Poland as well as in other countries of the European Union, the issue of energy efficiency in the construction industry and in energy systems, including centralized heating systems, is treated as a priority. This approach follows from a number of EU Directives and Polish regulations, which aim at reducing the use of primary fuels and pollutant emissions, mainly $\mathrm{CO}_{2}$. The current energy policies which, among others, have brought about the introduction of legal and organizational solutions that render it possible to obtain financial support for investment projects which improve energy efficiency, have changed the Polish and European construction and power industry considerably [1-5]. More and more frequently, the need to convert the existing municipal energy systems into intelligent systems that can be an element of Smart Energy Cities has been emphasized. One of the effects of the above mentioned changes is a gradual decrease in the contracted power and heat supplied by centralized heating systems. This problem is a live issue not only in Poland, but also in other European countries and globally. The importance of the problem is also evidenced in a broad range of literature on this subject [5-11]. In this context, it is of particular significance to look for new solutions which allow optimization of operation of municipal energy systems, first of all in the aspect of energy efficiency, but having regard also to ecological and economic conditions. Additionally, it should be underlined that research and implementation projects which are currently carried out in Poland and worldwide are focused on solutions which can be directly implemented in practice, and this forces the use of most modern solutions, frequently very innovative, previously unavailable on the market [12-18]. Such an approach is perfectly consistent with the concept of Smart Energy City [19-22].

\section{OPTIMIZATION OF MUNICIPAL ENERGY SYSTEMS}

The key element in the concept of Smart Energy City is the use of information technologies and information and communication technologies for the purpose of enhancing interactivity and efficiency of municipal infrastructure and its components, and also for raising public awareness. In respect of energy management of urbanized areas, the term "Energy" is important in the name of the concept. It underlines that in these areas municipal energy systems used for the generation and distribution of all types of energy, and also equipment of buildings, which affects efficient energy use, are subjected to analysis from the point of view of their performance and optimization.

Municipal energy systems, in the broad meaning, comprise municipal power grids, heating and cooling networks, heat substations in buildings, district or 
individual heat sources, including renewable energy sources, and also combined heat and power sources. The systems are extremely complicated, frequently territorially dispersed, and also diverse in terms of technology and ownership. As a consequence of this fact, the analysis referring to their technological aspects and optimization of their operation is a considerable challenge [23-25]. It should be carried out with the use of advanced analytical systems, supported with computer simulation methods and intelligent analytical systems. It is of crucial importance to base optimization of energy systems on multi-criteria analyses, taking into account all their elements, and to develop knowledge bases of intelligent analytical systems on the basis of operational data (consumption of electrical energy, heat, cooling, etc.) obtained from real buildings, sources of energy, heating and cooling and distribution networks. It is also essential to consider in the analyses the buildings which are supplied with electrical energy, heating and cooling by municipal energy systems. It should be emphasized that it is not possible to select appropriately elements of such systems without full knowledge about the structure of demand of buildings for various forms of energy, and also annual trends in the demand determined using a time step not exceeding one hour. A proper identification of energy performance of buildings renders it possible to evaluate technical parameters of energy systems, such as, among others, energy source power (heat, cooling, electrical energy), the flow of heating and cooling medium in distribution networks, capacity of local or group heat and cold storage tanks, technological scheme, power and equipment of a heat substation.

In the framework of the research and implementation project, the existing analytical methods and tools for optimization of municipal energy systems have been reviewed extensively. The results of the review indicate that research studies which are currently carried out, mostly concentrate on an approach to the analysis and optimization of energy systems based on one criterion. Additionally, very often, they cover only selected aspects of their operation. Research studies published in [26-33] may serve as an example. Research studies carried out in such a manner is of great scientific and practical value. They offer solutions to many complicated problems in the field of municipal power industry, for instance, they define the methodology of energy demand prediction [34-36] and optimize the procedures for controlling the operation of distribution networks $[27,29,32,37]$. It should be emphasized, however, that a definitely better approach to the issue of optimization of municipal energy systems as a whole is a complex analysis which takes into consideration energy sources, distribution networks and buildings supplied with energy. Only such a multi-criteria approach to research allows a detailed analysis of each aspect of municipal energy system operation and a recommendation - based on this analysis - on its configuration and operational algorithms in order to achieve the 
assumed energy, ecological and economic indicators. It applies both to energy sources and distribution systems, as well as to buildings supplied with energy and heat from such systems. Therefore, we should strive to develop tools which would allow an analysis and recommendation on possible solutions. Such a tool has been designed and implemented.

\section{INTELLIGENT, MULTI-CRITERIA SYSTEM FOR THE ANALYSIS AND OPTIMIZATION OF MUNICIPAL ENERGY SYSTEMS}

An intelligent multi-criteria system for the analysis and optimization of municipal energy systems (an intelligent analytical system) was developed within the framework of the research and implementation project, financed by the National Centre for Research and Development, entitled "Analysis of Technical and Functional Requirements for Buildings Supplied by Centralized Heat Sources", which was carried out as one of the tasks of the strategic project entitled "The Integrated System for Decreasing the Functional Energy Consumption of Buildings".

The intelligent analytical system is an integrated multi-module computer application developed with the use of the "R environment" (R project) and the ready-made EnergyPlus calculation engine [38, 39]. The concept of the system was based on the integration of many calculation tools for the purpose of creating a uniform computer system supported with knowledge bases which are based on operational investigations carried out in the course of the project. The objective of the intelligent analytical system is to perform energy performance analysis of a building or a group of buildings and also to make a recommendation concerning an optimum configuration of the system (local heat sources, centralized system, wide-spread generation of electrical energy and heat, etc.). The basic criteria taken into consideration in the analysis are: $\mathrm{CO}_{2}$ emissions and investment costs determined on the grounds of indicators contained in the knowledge bases. It should be stressed here that knowledge bases used in the intelligent analytical system have been developed on the grounds of actual operational data (consumption of electrical energy, heat and cold) which were measured in more than 1050 buildings localized in the West of Poland.

The fundamental elements of the intelligent, multi-criteria system for the analysis and optimization of municipal energy systems comprise:

- a module for entering and editing data of building/buildings,

- a module for the generation of input files to the simulation application (EnergyPlus) which calculates energy performance features of the buildings under investigation, 
- a simulation application based on the ready-made EnergyPlus calculation engine,

- a module for the generation of input files for the calculation and selection of energy source,

- an independent calculation module, prepared in the MATLAB and R environment, designed for the calculation and selection of an energy source for a building (including a centralized source) on the basis of $\mathrm{CO}_{2}$ emissions,

- a module for the analysis of investment costs of building a heating network together with an energy source for the needs of a group of buildings,

- an external module for the analysis of investment costs and recommendation on an energy source on the basis of $\mathrm{CO}_{2}$ emissions, and investment costs of the recommended energy source.

Each of the above mentioned parts of the intelligent analytical system is based on knowledge bases. All data about buildings, installations, energy sources, operating costs constitute knowledge databases which are based on the investigations and analyses carried out within the framework of the project. The intelligent analytical system allows corrections to be made to the data comprised in knowledge databases, at the level of building analysis and also for the purpose of complementing software functionality.

\subsection{Analysis of municipal energy system}

The intelligent analytical system, which was developed, renders it possible to analyse an energy system which comprises one building and also a group of buildings. From the point of view of quality of the analysis, it does not matter which kinds of buildings will be considered. Buildings of different types can be analysed when the system is in operation (multi-family residential buildings, single-family buildings, public facilities, office buildings). The intelligent analytical system both for a single building and a group of them performs all the analyses considering the following possibilities of making a recommendation related to a municipal energy system configuration, including in particular the decision concerning the choice of an energy source for a building or a group of buildings (Figure 1):

- an analysis of a single building - built-in microcogenaration unit, connection of the building to the existing heating system with a centralized heat source, built-in gas boiler room,

- an analysis of a group of buildings - gas boiler room built-in in each building separately, heating micro-network with a group heat source in the form of a gas boiler room, heating micro-network with a group heat 
source in the form of a microcogeneration unit, connection of the group of buildings to the existing heating system with a centralized heat source.

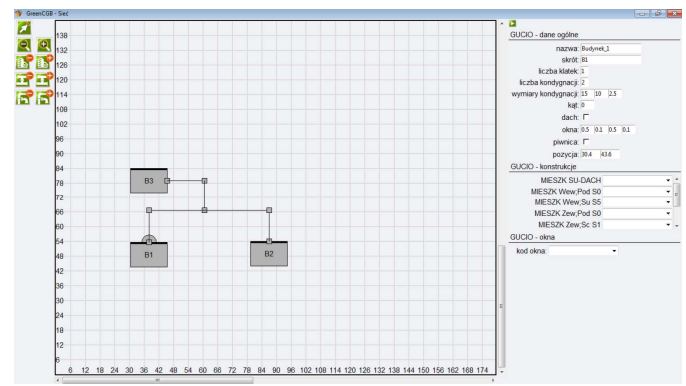

a)

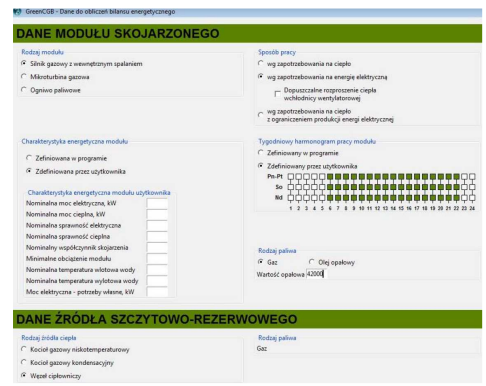

b)

Fig. 1. Exemplary stages of municipal energy system analysis: a) connection of buildings to heating micro-network, b) analysis of power and performance of the microcogeneration unit

The analysis carried out by the intelligent analytical system produces a list of recommendations on energy sources for either a single building or a group of them, which can be ordered in respect of both criteria at the same time, i.e., $\mathrm{CO}_{2}$ emissions and estimated investment costs, or in respect of only one criterion.

The intelligent analytical system algorithm and consequently its operations is divided into three stages which are carried out sequentially. In the first stage, energy performance calculations are made for a building or a group of buildings. At this stage, it is necessary to enter to the system all parameters which are essential from the point of view of energy performance of a building and/or buildings. A part of the data should be entered using the knowledge databases built-in into the system, whereas a part should be defined precisely on the basis of documentation or inventory of a given building. The intelligent analytical system makes it also possible to enter detailed information about the heating network, to which a building or a group of buildings may be connected. The geometry of the heating network is defined with the use of a graphic tool (Figure 1a), which permits drawing a scheme of the network, connections of buildings and indication of energy source. Each symbol in the drawing is active, i.e., it renders it possible to assign to an element of the system proper technical parameters which allow the assessment of investment costs. The next step of the algorithm at this stage is generation of input data for the energy performance analysis of a building and/or buildings. The analysis is made with the use of EnergyPlus software integrated with the intelligent analytical system. The data are generated on the basis of parameters entered into the intelligent analytical system, such as basic dimensions, number of segments, floors, percentage share of windows in the area of individual walls, heat transfer 
coefficients, etc. Even though the input data for energy simulation describe a building in a simplified manner, the results obtained in the form of annual trends in changes in building energy performance parameters (with an hourly step) are one hundred percent consistent with the simulation results for such buildings, which are obtained using a very detailed building model. This follows from the research conducted within the project, in which a method was developed for simplifying the computer model of a building in such a manner that it would not lower the quality of its energy performance simulation results. A detailed description of the research work and results obtained can be found in [40]. The second stage of the algorithm operation of the intelligent, multi-criteria system for the analysis of municipal energy systems (intelligent analytical system) begins with loading the annual trends in changes in building energy parameters generated in EnergyPlus simulations (*.csv file). It consists in a multi-criteria selection of a heat source for a building or a group of buildings. On the basis of additional parameters entered by the user, the intelligent analytical system calculates the instantaneous power demand for domestic hot water production and instantaneous electric energy consumption on a yearly basis. The results obtained and annual trends in changes in energy performance parameters of buildings determined in computer simulations constitute the basis for selection of a heat source. Figure 2 presents an example of a chart obtained in the intelligent analytical system illustrating the consumption of heat and electrical energy in a building.

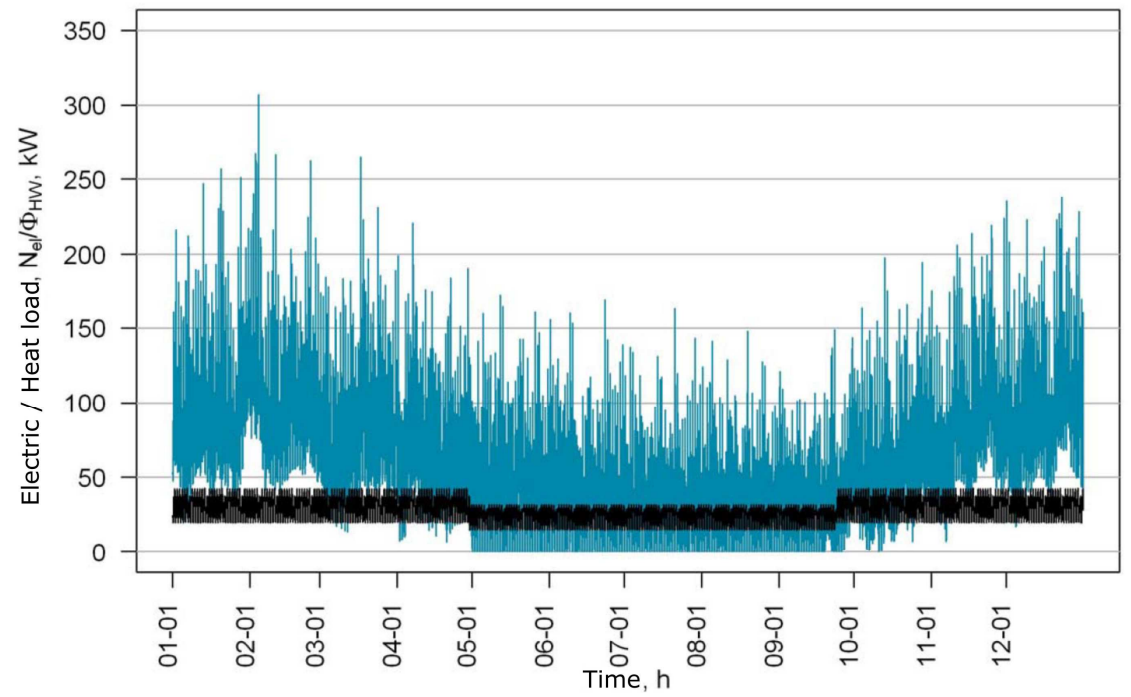

Fig. 2. Example of simulation results obtained in the intelligent analytical system for electrical energy and heat consumption in a building 
The intelligent analytical system allows the choice of many different sources of heat and electrical energy for a municipal energy system. For example, an analysis was carried out for three variants: a cogeneration source, a gas boiler room and for a connection of the building to the existing heating system. In the case of the cogeneration system, a gas boiler or a heat substation can be the peak source. The intelligent analytical system enables simulation of the cogeneration system operation according to the demand for heat or electrical energy. In order to conduct all the calculations and analyses at this step of the algorithm operation, it is also necessary to enter data of the centralized heat source, which describe unequivocally the most important features from the point of view of the intelligent analytical system operation, i.e., $\mathrm{CO}_{2}$, emissions factors, source efficiency and heat cost, ordered charts, power, etc. Upon supplementation of input data, the intelligent analytical system activates the module created in the $\mathrm{R}$ environment, which carries out all the necessary calculations and analyses energy sources (including the centralized source). This module also generates all the necessary charts and characteristics. Figure 3 shows an example of the simulation result for the operation of a cogeneration system with the electrical co-generation coefficient $\beta_{\mathrm{el}}=0.8$.

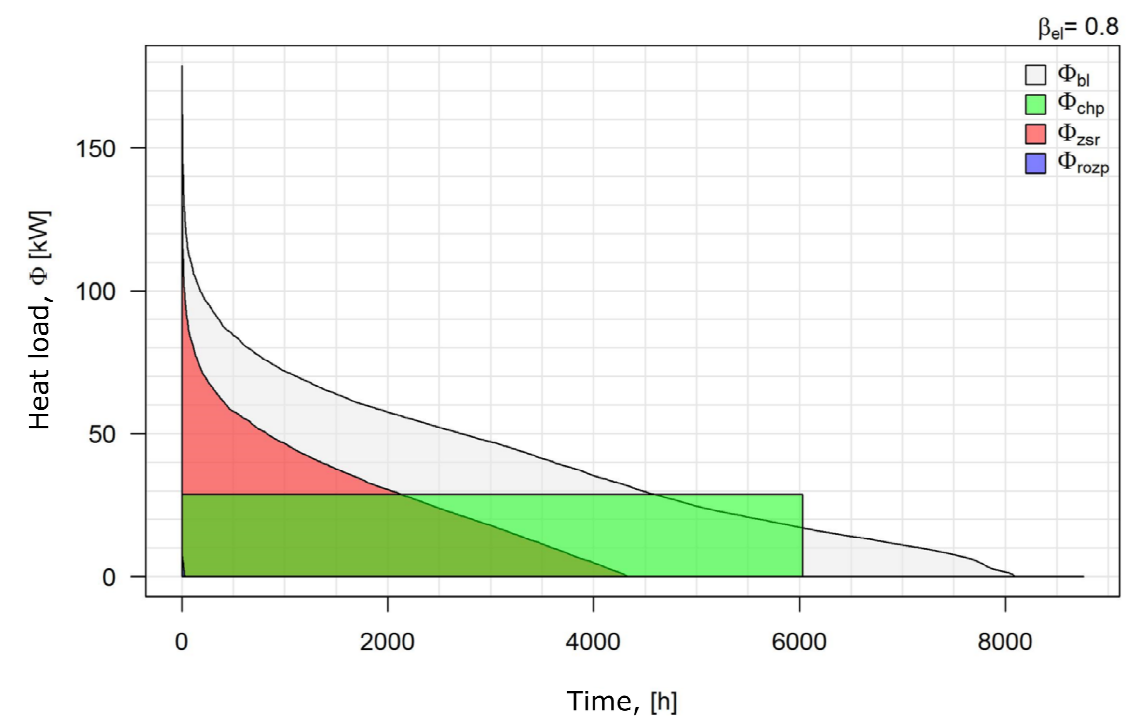

Fig. 3. Example of simulation results for the operation of a cogeneration system with the electrical co-generation coefficient $\beta_{\mathrm{el}}=0.8$ 
In stage 3 of the algorithm operation, the intelligent analytical system carries out economic analyses of investment projects in order to select an optimum solution from the point of view of operating costs and also with consideration given to investment costs. The result of the analysis is a set of data which make it possible to choose an optimum heat source on the basis of technical and economic algorithms. The data are entered to the module for the purpose of their analysis and recommending heat sources on the basis of the economic analysis (which includes, among others, investment project costs, fuel costs, costs of pollutant emissions, costs of obtaining emission certificates, operating costs, etc.). The module generates charts and characteristics which allow investigating and checking on, among others: additional EBIT (Figure 4) and EBITDA for an investment in a microcogeneration system, measures of economic effectiveness of the investment (NPV, IRR, discounted payback period) and others.

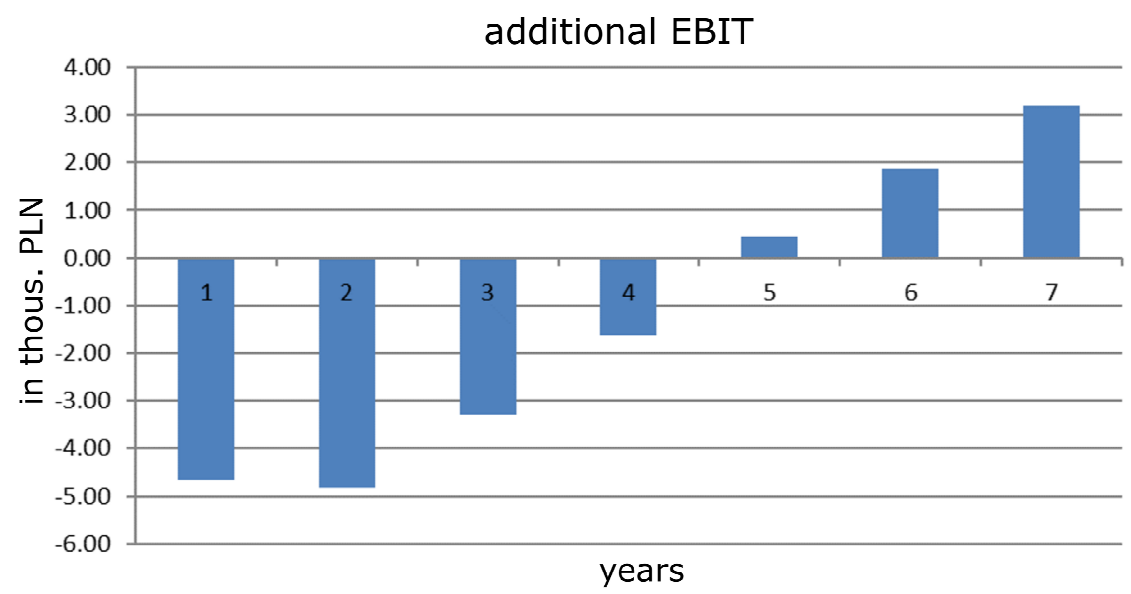

Fig. 4. Example of a chart showing changes in the operating profit (EBIT) as a function of time (years 1-7) for the variant with a microcogeneration unit

The reports generated reflect the characteristics of the investment entered into the system. The number of potential combinations concerning investment characteristics is large enough to make it possible to assess almost all cases related to an investment in a small-scale cogeneration source. The data thus obtained can be used, among others, for analysing the profitability of investing in a cogeneration source for a building or a group of buildings and for issuing a decision concerning Union funding. 


\section{CONCLUSIONS}

The intelligent analytical system is an advanced IT tool, based on solid mathematical fundamentals and extensive knowledge databases, designated for recommending a local or centralized heat source for a building or a group of buildings on the grounds of constructional or operational features. The software is perfectly suited for supporting investment decisions, planning investments connected with changing heat supply to buildings or small housing estates. Due to its expert character it can also be treated as an advisory tool for planning changes in energy policies of an urban area.

\section{REFERENCES}

1. Bačeković I., Østergaard P. A., A smart energy system approach vs a nonintegrated renewable energy system approach to designing a future energy system in Zagreb, Energy, vol. 155, pp. 824-837, Jul. 2018.

2. Yazdanie M., Densing M., Wokaun A., Cost optimal urban energy systems planning in the context of national energy policies: A case study for the city of Basel, Energy Policy, vol. 110, pp. 176-190, Nov. 2017.

3. Nilsson J. S., Mårtensson A., Municipal energy-planning and development of local energy-systems, Appl. Energy, vol. 76, no. 1-3, pp. 179-187, Sep. 2003.

4. Regulski B., Ziembicki P., Bernasiński J., Węglarz A., Rynek ciepłowniczy w Polsce, Rynek Energii, vol. 113, no. 4, pp. 9-16, 2014.

5. Wojdyga K., Chorzelski M., Chances for Polish district heating systems, Energy Procedia, vol. 116, pp. 106-118, Jun. 2017.

6. Hast A., Syri S., Lekavičius V., Galinis A., District heating in cities as a part of low-carbon energy system, Energy, vol. 152, pp. 627-639, Jun. 2018.

7. Paiho S., Reda F., Towards next generation district heating in Finland, Renew. Sustain. Energy Rev., vol. 65, pp. 915-924, Nov. 2016.

8. Balić D., Maljković D., Lončar D., Multi-criteria analysis of district heating system operation strategy, Energy Convers. Manag., vol. 144, pp. 414-428, Jul. 2017.

9. Dominković D. F., Wahlroos M., Syri S., Pedersen A. S., Influence of different technologies on dynamic pricing in district heating systems: Comparative case studies, Energy, vol. 153, pp. 136-148, Jun. 2018.

10. Morvaj B., Evins R., Carmeliet J., Optimising urban energy systems: Simultaneous system sizing, operation and district heating network layout, Energy, vol. 116, pp. 619-636, Dec. 2016. 
11. Ziemele J., Cilinskis E., Blumberga D., Pathway and restriction in district heating systems development towards $4^{\text {th }}$ generation district heating, Energy, vol. 152, pp. 108-118, Jun. 2018.

12. Gao L. et al., Technologies in Smart District Heating System, Energy Procedia, vol. 142, pp. 1829-1834, Dec. 2017.

13. Good N., Martínez Ceseña E. A., Mancarella P., Ten questions concerning smart districts, Build. Environ., vol. 118, pp. 362-376, Jun. 2017.

14. Yabanova I., Keçebaş A., Development of ANN model for geothermal district heating system and a novel PID-based control strategy, Appl. Therm. Eng., vol. 51, no. 1-2, pp. 908-916, Mar. 2013.

15. Lichtenegger K., Wöss D., Halmdienst C., Höftberger E., Schmidl C., Pröll T., Intelligent heat networks: First results of an energy-information-costmodel, Sustain. Energy, Grids Networks, vol. 11, pp. 1-12, Sep. 2017.

16. AlFaris F., Juaidi A., Manzano-Agugliaro F., Intelligent homes' technologies to optimize the energy performance for the net zero energy home, Energy Build., vol. 153, pp. 262-274, Oct. 2017.

17. Amber K. P., Ahmad R., Aslam M. W., Kousar A., Usman M., Khan M. S., Intelligent Techniques for Forecasting Electricity Consumption of Buildings, Energy, vol. 157, pp. 886-893, Aug. 2018.

18. Ziembicki P., Kozioł J., Mendecka B., Innowacyjne metody zarzadzania w energetyce komunalnej. Zielona Góra, Oficyna Wydawnicza Uniwersytetu Zielonogórskiego, 2018.

19. Calvillo C. F., Sánchez-Miralles A., Villar J., Energy management and planning in smart cities, Renew. Sustain. Energy Rev., vol. 55, pp. 273-287, Mar. 2016.

20. Mosannenzadeh F., Bisello A., Vaccaro R., D’Alonzo V., Hunter G. W., Vettorato D., Smart energy city development: A story told by urban planners, Cities, vol. 64, pp. 54-65, Apr. 2017.

21. Mosannenzadeh F., Di Nucci M. R., Vettorato D., Identifying and prioritizing barriers to implementation of smart energy city projects in Europe: An empirical approach, Energy Policy, vol. 105, pp. 191-201, Jun. 2017.

22. Calvillo C. F., Sánchez-Miralles A., Villar J., Energy management and planning in smart cities, Renew. Sustain. Energy Rev., vol. 55, pp. 273-287, Mar. 2016.

23. Rismanchi B., District energy network (DEN), current global status and future development, Renew. Sustain. Energy Rev., vol. 75, pp. 571-579, Aug. 2017.

24. Aghamolaei R., Shamsi M. H., Tahsildoost M., O'donnell J., Review of district-scale energy performance analysis: Outlooks towards holistic urban frameworks, Sustain. Cities Soc., vol. 41, pp. 252-264, Aug. 2018. 
25. Colmenar-Santos A., Rosales-Asensio E., Borge-Diez D., Blanes-Peiró J. J., District heating and cogeneration in the EU-28: Current situation, potential and proposed energy strategy for its generalisation, Renew. Sustain. Energy Rev., vol. 62, pp. 621-639, Sep. 2016.

26. Ahn J., Chung D. H., Cho S., Energy cost analysis of an intelligent building network adopting heat trading concept in a district heating model, Energy, vol. 151, pp. 11-25, May 2018.

27. Wang N. et al., Hydraulic resistance identification and optimal pressure control of district heating network, Energy Build., vol. 170, pp. 83-94, Jul. 2018.

28. Schmidt D. et al., Low Temperature District Heating for Future Energy Systems, Energy Procedia, vol. 116, pp. 26-38, Jun. 2017.

29. Vandermeulen A., van der Heijde B., Helsen L., Controlling district heating and cooling networks to unlock flexibility: A review, Energy, vol. 151, pp. 103-115, May 2018.

30. Johansson C., Bergkvist M., Geysen D., De Somer O., Lavesson N., Vanhoudt D., Operational Demand Forecasting in District Heating Systems Using Ensembles of Online Machine Learning Algorithms, Energy Procedia, vol. 116, pp. 208-216, Jun. 2017.

31. Li H., Wang S. J., Load Management in District Heating Operation, Energy Procedia, vol. 75, pp. 1202-1207, Aug. 2015.

32. Pizzolato A., Sciacovelli A., Verda V., Centralized control of district heating networks during failure events using discrete adjoint sensitivities, Energy, Sep. 2017.

33. Raatikainen M., Skön J. P., Leiviskä K., Kolehmainen M., Intelligent analysis of energy consumption in school buildings, Appl. Energy, vol. 165, pp. 416-429, Mar. 2016.

34. Petković D., Protić M., Shamshirband S., Akib S., Raos M., Marković D., Evaluation of the most influential parameters of heat load in district heating systems, Energy Build., vol. 104, pp. 264-274, Oct. 2015.

35. Izadyar N., Ong H. C., Shamshirband S., Ghadamian H., Tong C. W., Intelligent forecasting of residential heating demand for the District Heating System based on the monthly overall natural gas consumption, Energy Build., vol. 104, pp. 208-214, Oct. 2015.

36. Shamshirband S. et al., Heat load prediction in district heating systems with adaptive neuro-fuzzy method, Renew. Sustain. Energy Rev., vol. 48, pp. 760-767, Aug. 2015.

37. Ahn J. Cho S., Development of an intelligent building controller to mitigate indoor thermal dissatisfaction and peak energy demands in a district heating system, Build. Environ., vol. 124, pp. 57-68, Nov. 2017. 
38. R Core Team, R: A Language and Environment for Statistical Computing. Vienna, 2017.

39. US Department of Energy, 'EnergyPlus Engineering Reference: The Reference to EnergyPlus Calculations', 2010.

40. Klimczak M., Bojarski J., Ziembicki P., Kȩskiewicz P., Analysis of the impact of simulation model simplifications on the quality of low-energy buildings simulation results, Energy Build., vol. 169, pp. 141-147, Jun. 2018.

\title{
OPTYMALIZACJA MIEJSKICH SYSTEMÓW ENERGETYCZNYCH PRZY WYKORZYSTANIU INTELIGENTNEGO SYSTEMU ANALITYCZNEGO
}

\begin{abstract}
Streszczenie
W miejskich systemach energetycznych optymalna konfiguracja przestrzenna, technologia wytwarzania ciepła, moc źródeł ciepła i ich wydajność energetyczna są kluczowymi zagadnieniami $\mathrm{z}$ punktu widzenia negatywnego wpływu na środowisko i komfortu życia. Obecnie, zarówno w Polsce, jak i na całym świecie, brakuje zaawansowanych narzędzi analitycznych, a także usług doradczych, które mogłyby być wykorzystywane do kompleksowej analizy takich systemów. Narzędzia tego typu powinny umożliwić opracowanie zaleceń mających na celu przekształcenie istniejących miejskich systemów energetycznych w nowoczesne, wysokowydajne, ekologiczne i inteligentne systemy typowe dla "Smart Energy Cities".

W artykule przedstawiono system analityczno-doradczy, którego celem jest kompleksowa, wielokryterialna analiza efektywności energetycznej budynku lub grupy budynków oraz przedstawienie rekomendacji dla źródła energii z uwzględnieniem emisji $\mathrm{CO}_{2}$ i kosztów inwestycji określonych na podstawie. System analityczno-doradczy wykorzystuje zaawansowane komputerowe symulacje energetyczne budynków oraz innowacyjne algorytmy analityczne opracowane przez autorów, w tym oparte na bazach wiedzy zbudowanych $\mathrm{z}$ wykorzystaniem danych zebranych $\mathrm{w}$ czasie inwentaryzacji budynków zlokalizowanych w kilkunastu miastach w Polsce.

Część prac badawczych przedstawionych $\mathrm{w}$ publikacji została przeprowadzona w ramach programu strategicznego finansowanego przez Narodowe Centrum Badań i Rozwoju.
\end{abstract}

Słowa kluczowe: systemy energetyczne, symulacja, optymalizacja, inteligentne systemy analityczne, Smart Energy City

Editor received the manuscript: 20.09 .2018 